\title{
AKTUALISASI NILAI-NILAI KONSTITUSI DALAM KEBIJAKAN PERDAGANGAN INDONESIA DI TINGKAT REGIONALDAN MULTILATERAL
}

\author{
Dias Satria \\ Farah Wulandari \\ Fakultas Ekonomi \& Bisnis Universitas Brawijaya
}

\begin{abstract}
The purposes of this study were to analyze the implementation of the Indonesian constitutional values in Indonesia and in the regional level of trade policies (AFTAASEAN Free Trade Area). The method used is a qualitative approach. The findings of this research stated that there are some trade policy that misses thebasic values of the 1945 Constitution and Pancasila, resulting inmismanagement in development policy and therefore contributesto lowering the level of public welfare in general. The policy, among others, is the policy of trade protection is not based on the principle of wealth creation and equitable distribution, but is based on the behavior of crony-capitalism; government policiesrelated to foreign ownership in an investment is still not heedingthe values and principles of broad benefit of welfare, justice andequity; and government protection policies in the agriculturalsector is still not optimal to create a high competitiveness.
\end{abstract}

Keywords: constitution, international trade, welfare and equity.

\section{A. LATAR BELAKANG}

Eksistensi indonesia dalam kancah perdagangan internasional baik diskala bilateral, regional dan multilateral tentunya masih belum dapat dianggap berhasil. Hal ini dapat dilihat dari kinerja transaksi berjalan (current account) dan devisa yang masih belum maksimal jika dibandingkan dengan beberapa negara emerging markets lainnya. Kinerja perdagangan Indonesia semakin buruk tatkala kompetisi global semakin ketat dan integrasi perdagangan dengan kutub-kutub kekuatan baru mulai muncul, seperti: China dan India. Tidak hanya itu, tantangan eksternal shock "krisis keuangan dunia" juga semakin memperlambat proses recovery ekonomi dunia yang sedang berjalan, yang juga berdampak secara langsung terhadap kinerja perdagangan Indonesia.

Dalam kebijakan perdagangan, Pemerintah Indonesia telah melakukan kebijakan strategis baik di tingkat bilateral, regional maupun multilateral. Di tingkat bilateral, kerjasama perdagangan diintenskan dengan negara-negara maju, seperti: Amerika Serikat, Australia dan China. Hal ini dapat dilihat dari proses lobi pimpinan kedua negara untuk menjajaki kerjasama yang lebih intensif. Selanjutnya di tingkat regional, Indonesia dan negara-negara anggota ASEAN (Association of South East Asia Nation) sepakat untuk meningkatkan kerjasama intra-trade dengan membentuk 
AFTA (ASEAN Free Trade Area). Dalam kerjasama ini juga dikembangkan lebih luas dengan mengundang China sebagai salah satu anggota dalam kerjasama perdagangan tersebut. Kerjasama ini dikenal dengan istilah ACFTA (ASEAN-China Free Trade Area). Terakhir, eksistensi Indonesia dalam perdagangan internasional dapat dilihat dari keikutsertaan Indonesia sebagai anggota WTO (World Trade Organization).

Kebijakan perdagangan internasional Indonesia seperti yang telah diuraikan diatas tentu memiliki efek yang luas terhadap sendi-sendi kehidupan masyarakat. Beberapa ancaman pengangguran, inflasi dan instabilitas bahkan kerap terjadi sebagai akibat pilihan kebijakan perdagangan yang salah. Melihat seriusnya dampak yang ditimbulkan dari kebijakan perdagangan Indonesia, maka perlu dikaji keterkaitan antara kebijakan-kebijakan perdagangan dengan nilainilai dasar dan acuan konstitusi Indonesia yaitu Undang-Undang Dasar 1945. Pentingnya penelaahan ini adalah untuk menjamin sebuah dinamika ekonomi yang berisi keadilan yang pasti, kepastian yang adil serta kebergunaan bagi masyarakat Indonesia.

Dengan adanya penelaahan kebijakan perdagangan dengan konstitusi maka diharapkan pengawasan dan pengaturan atas kekuasaan pemerintah atau kewenangan pemerintah dalam kebijakan dapat ditingkatkan guna meminimalisir efek negatif kebijakan yang merugikan dan hanya mementingkan kelompok-kelompok masyarakat tertentu atau trading partner saja.

Masalah-masalah perdagangan internasional di tingkat multilateral adalah sebuah pilihan yang sangat sulit bagi Indonesia. Pertama, jika Indonesia menarik diri dari perdagangan internasional maka kesempatan Indonesia untuk melakukan perluasan ekspor akan semakin terhambat. Disisi lain, Indonesia akan dikucilkan dalam kancah perdagangan internasioal, karena dianggap tidak patuh terhadap regulasi dan konsensus internasional. Namun jika Indonesia tetap bergabung dalam kesepakatan WTO, maka posisi Indonesia sebagai negara berkembang juga sangat dirugikan. Hal ini disebabkan karena ketentuan hak bersuara yang berbeda atau diskriminatif bagi negara berkembang dan maju. Selain itu dengan keikutsertaan Indonesia dalam WTO maka kedaulatan atau ekslusivitas pengaturan negara akan semakin berkurang seiring dengan konstitusi internasional yang harus disepakati setiap anggota.

Selain itu, meski WTO telah melakukan kesepakatan baru dalam Doha Development Round dengan memberikan treatment dan kebijakan yang berbeda bagi negara berkembang yang diberi nama "Special and Differential Treatment", namun pelanggaran atas kebijakankebijakan perdagangan yang dilakukan oleh negara maju tetap saja berlangsung. Masalah-masalah yang timbul dalam skala multilateral, antara lain: Pertama, di tingkat multilateral hak suara dan posisi negara berkembang dalam proses bargaining ketika terjadi dispute dalam perdagangan sangatlah lemah sehingga menyebabkan kebijakan-kebijakan di tingkat multilateral dikuasai oleh kepentingan-kepentingan negara-negara maju. Kedua, kebekuan dalam kesepakatan multilateral (Freezing in multilateral system) yang menyebabkan terhambatnya perdagangan antar negara-negara anggota. Secara umum, permasalahan dasar yang dialami dalam perdagangan multilateral berpusat pada egosentris masing-masing blok, dimana didalamnya termasuk Amerika, Eropa dan Negara-negara berkembang. Yang dalam konteks ini, US dianggap belum mau mengurangi sepenuhnya subsidi besar di sektor pertanian, Eropa yang menutup diri dari barang pertanian dari Negara lain dan Negara berkembang yang merestriksi impor manufaktur dari Negara maju. 
Kebekuan dalam kesepakatan multilateral inilah yang juga mendorong preferensi beberapa Negara untuk membentuk formasi perdangan regional, seperti: European Union (EU), North American Free Trade Area (NAFTA), ASEAN Free Trade Area (AFTA) dll. Secara spesifik, beberapa pertimbangan Negara-negara melakukkan kerjasama secara regional, antara lain: Pertama, tren regionalisme cenderung membatasi level of playing field yang cenderung sama. Dimana Negara-negara tersebut biasanya tidak jauh berbeda secara ekonomi. Kedua, tren regionalisme relevan secara teoritis (teori gravitasi), yang mana menyebutkan Negara-negara yang secara geografi dekat memiliki keuntungan dalam biaya transportasi yang semakin murah. Ketiga, tren regionalisme biasanya juga membawa agenda-agenda penting dalam membangun kekuatan kawasan, yang juga menjadi respon atas apa yang dilakukkan oleh Negara-negara di belahan dunia lainnya. Agenda-agenda penting tersebut, antara lain: kerjasama bidang keuangan, investasi dll. Keempat, tren regionalisme tidak bisa dihindari karena lambatnya penanganan masalah perdagangan multilateral (dispute and settlement), yang membuat kebekuan dalam perdagangan. Serta, perasaan senasib bagi Negara-negara yang merasakan ketidak fair an dalam perdagangan bebas.

Namun kebijakan kerjasama regional AFTA memiliki permasalahan yang serius tatkala China ikut serta sebagai anggota yang akan menikmati kebebasan perdagangan non tarrif. Kehandalan China dalam mempengaruhi pola perdagangan dunia memang tidak dapat dihiraukan. Negara yang sejak tahun 2001 telah menjadi anggota (World Trade Organization) WTO ini, tengah mengalami masa-masa kesuburan dalam pembangunan ekonomi dan perdagangan. Selain itu, pertumbuhan ekspor China yang rata-rata mencapai $20 \%$ setiap tahunnya telah mengusai lebih dari $6 \%$ dari total pangsa pasar dunia. Namun apakah masuknya China dalam kesepakatan ACFTA dapat menciptakan perdagangan yang menguntungkan bagi anggota ASEAN (Trade Creation)? Atau malah perdagangan bebas ini hanya menjadi sarana ekspansi produk bagi China untuk memperluas market share nya?.

Alasan paling sederhana yang kontra terhadap masuknya China adalah karena ditakutkannya barang-barang Impor China yang murah akan membanjiri pasar domestik, sehingga akan menggeser barang-barang produksi lokal yang tidak mampu bersaing. Dengan adannya tariff pun, barang impor China sudah memiliki keunggulan daya saing yang luar biasa, sehingga jika tariif dibebaskan hingga $0 \%$ maka bisa dipastikkan instabilitas sosial, ekonomi dan politik akan sangat mungkin terjadi terutama jika efeknya meluas hingga pemutusan hubungan kerja (PHK) dengan jumlah yang besar.

Alasan tersebut patut ditelaah mengingat hampir diseluruh dunia belum ada Negara yang secara efisien mampu memproduksi barang layaknya China. Meski kita pun menyadari bahwa ada alasan-alasan lain yang mendorong para petinggi ASEAN untuk menyetujui kerjasama dengan CHINA. Beberapa faktor tersebut, antara lain: Pertama, Pangsa pasar dunia (Amerika, Eropa, Australia dll) yang dikuasai China diharapkan dapat mendorong Investasi perusahaanperusahaan China di Negara-negara di ASEAN. Kedua, Kebutuhan Ekspor China ke Negaranegara Maju tentu memerlukan sokongan bahan baku (raw material) yang besar, dan hal ini mungkin bisa disupport oleh Negara-negara di ASEAN. Ketiga, Era fragmentasi produksi (Produksi yang terpecah-terpecah) mendorong China untuk membagi-bagi bagian produksi barangbarang manufakturnya ke Negara-negara di ASEAN dengan tujuan pencapaian efisiensi yang lebih tinggi. 
Dengan adanya peluang dan ancaman eksternal inilah maka Indonesia harus secara lebih proaktif untuk meningkatkan strategi perdagangannya. Hal ini dimaksudkan agar ekses negatif dari kerjasama perdagangan tersebut dapat diminimalisir. Sejalan dengan hal tersebut, maka aktualisasi nilai-nilai konsitusi UUD 1945 dan Pancasila yang telah dikembangkan sejak dulu harus dapat diimplementasikan secara tepat agar kebijakan perdagangan dan hubungan internasional yang dibangun dapat secara optimal mensejahterakan masyarakat Indonesia. Hal ini menjadi sangat penting untuk memberikan guideline dan arah pembangunan yang lebih jelas.

Selain itu, di samping kecenderungan terjadinya konstitusional kebijakan ekonomi, gejala konstitusionalisasi juga terjadi dalam kaitannya dengan perkembangan hukum ekonomi internasional. Hal yang paling sederhana dapat dilihat dari proses globalisasi ekonomi yang mengakibatkan integrasi dalam domain ekonomi, budaya dan politik. Fenomena globalisasi ekonomi itu berkembang sedemikian kuat dan cepatnya sehingga memaksa negara-negara di dunia duduk berunding untuk memperbaiki norma-norma aturan global di bidang perdagangan antarnegara. Kecenderungan demikian ini pada saatnya membentuk suatu sistem norma yang sangta kuat dan bahkan mengatasi sistem hukum dan konstitusi yang berlaku dan mengikat di masing-masing negara anggota. Dengan terbentuknya WTO, banyak instrumen hukum Internasional di bidang perdagangan ditetapkan dan mengikat semua negara anggota yang sampai sekarang sudah mencakup sekitar 95 persen pasar dunia. Oleh sebab itu, instrumen-instrumen hukum perdagangan internasional itu lama kelamaan menjadi penentu dinamika perdagangan di negara-negara anggotanya. Instrumen-instrumen hukum internasional di bidang perdagangan itu tidak ubahnya berfungsi sebagai semacam konstitusi ekonomi di masing-masing negara anggota WTO.

Hal inilah yang seharusnya dapat dianalisis secara lebih kritis, apakah kebijakan perdagangan telah memberikan sebuah peningkatan dalam pengembangan kualitas kesejahteraan masyarakat Indonesia yang lebih baik? Oleh karena itu perlu dikaji juga apakah kebijakan perdagangan yang dipilih oleh Indonesia telah sejalan dengan konstitusinya yang memang telah mengamanatkan kesejahteraan bagi masyarakat Indonesia, dan sesuai dengan prinsip-prinsip yang dianut sesuai dengan kepribadian bangsa. Oleh karena itu, kajian ini bertujuan untuk menganalisis aktualisasi nilai-nilai konstitusi Indonesia dalam kebijakan perdagangan Indonesia; dan juga untuk menganalisis aktualisasi nilai-nilai konstitusi Indonesia dalam kebijakan perdagangan internasional di tingkat Regional (AFTA-ASEAN Free Trade Area).

\section{B. TINJAUAN TEORITIS}

\section{Konstitusi}

Secara definitif, konstitusi berasal dari bahasa latin yaitu constitutio. Istilah tersebut berhubungan dengan kata "jus" atau "ius" yang memiliki pengertian hukum atau prinsip. Selanjutnya, dalam kamus hukum Bahasa inggris, Oxford Dictionary of Law, perkataan "constitution" diartikan sebagai the rules and practices that determine the composition and functions of the organs of the central and local government in a state and regulate the relationship between individual and state. 
Secara umum konstitusi selalu menjadikan kekuasaan sebagai pusat perhatian, karena kekausaan itu sendiri pada intinya memang perlu diatur dan dibatasi sebagaimana mestinya. Konstitusionalisme, seperti dikemukakan oleh Friedrich, didefinisikan sebagai "an institutionalized system of effective, regularized restraints upon governmetal action" (suatu sistem yang terlembgaan menyangkut pembatasan yang efektif dan teratur terhadap tindakan-tindakan pemerintahan). Dalam pengertian demikian, persoalan yang dianggap penting dalam setiap konstitusi adalah pengaturan mengenai pengawasan atau pembatasan terhadap kekuasaan pemerintah. Berlakunya suatu konstitusi sebagai hukum dasar yang mengikat didasarkan kekuasaan tertinggi atau prisip kedaulatan yang dianut dalam suatu negara.

Teori Carl Schmidt dalam bukunya Verfassungslehre (1928) menjelaskan bahwa konsep konstitusi dapat dipahami menjadi empat kelompok, yaitu: Pertama, konstitusi dalam arti absolute (absoluter verfasunbegriff atau absolute concept of the constitution); Kedua, konstitusi dalam arti relatif (relativer verfassungbegriff atau relative concept of the constitution); Ketiga, konstitusi dalam arti positif (der positive verfassungbegriff atau positive concept of the constitution); dan Keempat, konstitusi dalam arti ideal (idealbegriff der verfassung atau ideal concept of the constitution) (Jimly, 2010).

Per Krussel dan Jose Victor Rios Rull menjelaskan keterkaitan yang sangat erat antara pertumbuhan ekonomi dengan proses-proses berkonstitusi. Hal ini menunjukkan bahwa kebutuhan regulasi oleh negara tidak saja berkembang di negara-negara sosialis dan komunis, tetapi juga di lingkungan negara-negara liberal barat yang menerapkan sistem ekonomi pasar. Hal tersebut juga menunjukkan bahwa meski mereka menganut system pasar namun tetap saja diperlukan intervensi negara dalam bentuk regulasi dan perizinan dalam proses pembangunan ekonomi dan pengendalian pasar bebas. Pengaturan-pengaturan yang demikian diperlukan dalam rangka jaminan sistem rujukan bersama antara pemangku kepentingan (stake-holders) dalam dinamika ekonomi pasar (Jimly, 2010).

Dengan pengaturan inilah maka kepastian yang adil, keadilan yang pasti, dan kebergunaan itulah hukum dapat menjamin kebebasan yang teratur dalam dinamika perekonomian. Dalam hal ini, tanpa kepastian hukum (certainty) perekonomian tidak dapt berkembang dengan teratur; tanpa keadilan (justice), perekonomian tidak akan menumbuhkan kebebasan yang sehat berkeadilan adil; dan tanpa kebergunaan (utility), perekonomian tidak akan membawa kesejahteraan dan kedamaian. Karena pada akhirnya, hukum itu sendiri haruslah membawa kehidupan bersama kepada kesejahteraan dan kedamaian hidup bersama.

Oleh karena itu, hukum dapat difungsikan sebagai sarana penggerak dan pengarah guna mencapai tujuan-tujuan suatu masyarakat di bidang ekonomi. Artinya, hukum dapat berfungsi sebagai sarana pembaruan masyarakat (tool of social engineering), dan bahkan sebagai sarana pembebasan dan emansipasi social (tool of social liberation and social emancipation). Namun yang urgent untuk dikembangkan adalah apa yang telah disepakati bersama sebagai kebijakan ekonomi tertinggi dalam konstitusi, sehartusnya dapat jadikan pegangan dalam mengerakkan roda perekonomian yang berkembang dinamis mengikuti irama pasar. Dalam konteks ini kita harus selalu berpijak pada undang-undang dasar sebagai kontitusi ekonomi yang berfungsi sebagai sarana pengendalian perubahan (tool of social control) yang sekaligus sebagai sarana perekayasaan perubahan (tool of social engineering) dan sarana pembaruan, 
pembebasan, dan emansipasi masyarakat (tool of social reform, social liberation, social emancipation) (Jimly, 2010).

Selanjutnya, fenomena globalisasi ekonomi telah berkembang dengan sangat cepat. Globalisasi telah mendorong muncul dan berkembangnya regionalisme ekonomi yan pada gilirannya memerlukan pola-pola pengaturan baru dalam hubungan antarnegara di wilayahwilayah dimaksud. Dalam konteks ini, dapat dikatakan bahwa ada dua perkembangan penting yang dapat dijadikan rujukan, yatu kebutuhan untuk melakukan konstitusionalisasi pada tingkat global yang terkait dengan World Trade Organization (WTO) dan kebutuhan pada tingkat regional untuk mengembangkan norma-norma aturan yang mengikat bersama di antara sesama anggota AFTA (ASEAN FREE TRADE AREA) (Jimly, 2010).

Adanya WTO, banyak instrumen hukum Internasional di bidang perdagangan ditetapkan dan mengikat semua negara anggota yang sampai sekarang sudah mencakup sekitar 95 persen pasar dunia. Dengan demikian, maka akan timbul persoalan mengenai kedaulatan masing-masing negara untuk mengatur tersendiri persoalan ekonomi dan perdagangannya. Akan tetapi, oleh karena fenomena globalisasi perekonomian dunia berlangsung sangat cepat dan meluas, dinamika perekonomian di suatu negara tidak dapat lagi dikelola secara ekslusif. Oleh sebab itu, instrumeninstrumen hukum perdagangan internasional itu lama kelamaan menjadi penentu dinamika perdagangan di negara-negara anggotanya. Fenomena inilah yang pada akhirnya dapat menyebabkan permasalahan konstitusional kebijakan ekonomi. Dimana intervensi asing secara tidak langsung dapat mempengaruhi pola kebijakan ekonomi suatu negara (Jimly, 2010).

Dalam kebijakan WTO, setidaknya ada beberapa hal yang diatur secara bersama antara lain:

1. Perjanjian Pembentukan WTO;

2. Barang dan Investasi "Multilateral Agreements on Trade in Goods" termasuk GATT 1994 dan "Trade Related Investment Measures";

3. Services, "the General Agreement on Trade in Services"

4. Intelectual property, "the Agreement on Trade-Related Aspects of Intellectual Property Rights (TRIPS);

5. Penyelesaian sengketa, "dispute settlement (DSU); dan

6. Reviews of Government's rade policies (TPRM)

Fenomena ini tentu saja merupakan hal yang unik dimana perkembangan global ini tentu akan berpengaruh dan mempengaruhi atau bahkan semakin mempengaruhi konstitusi-konstitusi berbagai negara nasional di dunia yang belum mengadopsi gagasan konstitusionalisasi kebijakankebijakan ekonomi sosial (Jimly, 2010).

\section{ASEAN Free Trade Area (AFTA)}

Seiring dengan perkembangan ekonomi yang terintegrasi antara satu negara dengan negara lain, semakin berkembang pula kerjasama-kerjasama antar negara dalam perdagangan internasional yang saling menguntungkan. Kerjasama antar negara tersebut lebih dikenal dengan istilah Free Trade Area (FTA), dimana yang menjadi anggota adalah negara-negara yang berada dalam satu kawasan tertentu. Namun ada pula yang tidak dibatasi oleh wilayah geografisnya, 
salah satu contoh kerjasama FTA adalah terbentuknya AFTA (ASEAN Free Trade Area) yang negara-negara anggotanya berada di kawasan Asia Tenggara.

Pertama kali terbentuknya Association of Southeast Asia Nations (ASEAN) digagas oleh 5 negara di kawasan Asia Tenggara yaitu Indonesia, Malaysia, Filipina, Singapura, dan Thailand pada 8 Agustus 1967. Pada tahun 1984 Brunei Darussalam turut bergabung yang kemudian diikuti oleh Vietnam di tahun 1995. Lalu Laos, Kamboja, dan Myanmar ikut bergabung pada tahun 1999 sehingga jumlah total anggota ASEAN saat ini adalah sepuluh negara. Pada awalnya ASEAN merupakan sebuah forum regional yang bertujuan untuk mempromosikan keamanan regional dan stabilitas kondisi politik di kawasan Asia Tenggara.

Tujuan utama dibentuknya ASEAN seperti yang tercantum di dalam Deklarasi Bangkok adalah untuk:

1. Mempercepat pertumbuhan ekonomi, kemajuan sosial, serta pengembangan kebudayaan di kawasan Asia Tenggara melalui usaha bersama dalam semangat persahabatan dan kesamaan untuk memperkokoh landasan sebuh masyarakat bangsa-bangsa Asia Tenggara yang sejahtera dan damai.

2. Meningkatkan perdamaian dan stabilitas regional dengan menghormati keadilan dan tertib hukum di dalam hubungan antara negara-negara di kawasan Asia Tenggara serta mematuhi prinsip-prinsip Piagam Perserikatan Bangsa-Bangsa.

3. Meningkatkan kerjasama aktif serta saling membantu dalam segala permasalahan yang menjadi kepentingan bersama di bidang-bidang ekonomi sosial, teknik, ilmu pengetahuan, dan administrasi.

4. Saling memberikan bantuan dalam bentuk sarana prasarana pelatihan dan penelitian dalam bidang-bidang pendidikan, profesi, teknik, dan administrasi.

5. Bekerjasama secara lebih efektif untuk meningkatkan pemanfaatan pertanian dan industri negara-negara anggota ASEAN, memperluas perdagangan, melakukan pengkajian terhadap masalah-masalah komoditi internasional, memperbaiki sarana-sarana pengangkutan dan komunikasi, serta meningkatkan taraf hidup rakyatnya.

6. Memajukan pengkajian mengenai Asia Tenggara dalam berbagai bidang.

7. Memelihara kerjasama yang erat dan berguna dengan berbagai organisasi internasional dan regional lain yang memiliki tujuan serupa, serta untuk menjajagi segala kemungkinan untuk saling bekerjasama secara erat di antara negara-negara ASEAN anggota sendiri.

Prinsip paling utama di dalam kerjasama ASEAN antara lain adalah persamaan kedudukan dalam keanggotaan (equality), dengan tanpa mengurangi kedaulatan masing-masing negara anggota. Negara-negara anggota ASEAN sepenuhnya tetap memiliki kedaulatan ke dalam maupun ke luar negara (sovereignty). Sedangkan cirri-ciri kerjasama ini adalah musyawarah (consensus and consultation), kepentingan bersama (common interest), dan saling membantu (solidarity) dengan semangat ASEAN. ${ }^{1}$

1 Lebih lengkapnya dapat dilihat di situs resmi ASEAN : ww w.aseanec.org 
Seiring dengan perkembangan konstelasi global, ASEAN pun turut mengalami perkembangan pesat sejalan dengan globalisasi dunia. Pada tahun 1992 ASEAN mulai menunjukkan identitas ekonominya ketika negara-negara anggotanya memutuskan untuk membentuk sebuah forum khusus yakni ASEAN Free Trade Area (AFTA). Perkembangan ASEAN tersebut memasuki babak baru dengan diadopsinya Visi ASEAN 2020 di Kuala Lumpur, Malaysia tahun 1997 yang mencita-citakan ASEAN sebagai komunitas negara-negara Asia Tenggara yang terbuka, damai, stabil, sejahtera, serta saling peduli yang diikat bersama dalam kemitraan yang dinamis di tahun $2020 .^{2}$

\section{Free Trade Area (FTA)}

Dengan terbentuknya FTA, setiap negara anggota akan melonggarkan kebijakan perdagangannya dengan sesama negara anggota namun tetap tidak melanggar kedaulatan negara masingmasing. Dengan terbentuknya kawasan FTA akan memberikan keuntungan bagi negara-negara anggotanya. Kebijakan perdagangan yang diterapkan antara negara anggota dengan negara non-anggota akan berbeda, semisal dalam hal pengenaan tarif bagi sesama negara anggota akan digunakan kebijakan tarif rendah dan sebaliknya bagi negara non anggota tetap dikenai kebijakan tarif tinggi. Menurut Appleyard et al (1998), terdapat beberapa manfaat yang didapat karena terbentuknya FTA bagi negara-negara anggotanya adalah terjadinya trade creation dan trade diversion.

Trade Creation ${ }^{3}$ terjadi apabila integrasi ekonomi mendorong suatu pergeseran produksi dari produsen dalam negeri (yang memiliki biaya produksi lebih tinggi) ke produsen di negara anggota lain (yang memiliki biaya produksi lebih rendah). Sedangkan Trade Diversion ${ }^{4}$ terjadi apabila integrasi ekonomi mendorong suatu pergeseran produksi dari produsen di negara yang bukan anggota (yang memiliki biaya produksi lebih tinggi) ke produsen di negara anggota (yang memiliki biaya produksi lebih rendah), sehingga dengan demikian perdagangan dari negara bukan anggota dialihkan menjadi perdagangan dengan negara anggota.

Selain itu, terjadi pula pemanfaatan bersama sumber daya regional dan peningkatan efisiensi akibat dari terbentuknya spesialisasi di antara para pelaku industri dan perdagangan yang terpacu oleh adanya insentif liberalisasi tarif dan non-tarif. Dalam kerangka FTA, posisi tawar ekonomi regional menjadi lebih kuat dalam menarik mitra dagang dan investor asing maupun domestik yang pada akhirnya akan meningkatkan kesejahteraan penduduk negara anggota. Menurut Salvatore (1993), selain untuk menigkatkan kesejaheraan penduduknya, FTAjuga dibentuk untuk mendapatkan manfaat dinamis yang signifikan dari mengingkatnya kompetisi, skala ekonomi,

2 Analisis Hubungan Perdagangan ASEAN dan Australia oleh Binsar Panjaitan (2008). Departemen Perdagangan RI.

3 Trade Creation menciptakan transaksi dagang antar anggota FTA yang sebelumnya tidak pernah terjadi karena adanya insentif-insentif dari terbentuknya FTA. Sebagai contoh, Kamboja tidak pernah mengimpor obat-obatan, namun setelah bergabung dengan ASEAN, seiring berjalannya waktu, tercipta daya beli yang menyebabkan Kamboja memiliki devisa cukup untuk mengimpor obat dari Indonesia.

4 Trade Diversion terjadi akibat adanya insentif penurunan tarif. Sebagai contoh, Indonesia yang sebelumnya selalu mengimpor gula hanya dari Cina beralih mengimpor gula dari Thailand karena harganya menjadi lebih murah. 
stimulus investasi baik asing maupun domestik, dan penggunaan yang lebih baik terhadap sumber daya ekonomi.

Kesepakatan yang paling utama dalam perdagangan bebas adalah penghapusan hambatan tarif dan non-tarif di antara negara anggota FTA karena pinsip objektifnya adalah liberalisasi perdagangan dan peningkatan kesejahteraan untuk negara-negara anggotanya. Dasar pemikiran FTA yang merupakan perdagangan internasional secara langsung dan siginifikan akan mendorong kesejahteraan (Raimonds-Moller and Woodland, 2002 dalam Panjaitan, 2008), pertumbuhan ekonomi dan pembangunan negara-negara berkembang (Harrison, 1996, Frankel et al., 1996, Tran Van Hoa, 2002 dalam Panjaitan, 2008).

\section{METODE PENELITIAN DAN ANALISIS DATA}

Metode analisis yang digunakan dalam penelitian ini adalah penelitian kualitatif. Menurut Strauss dan Corbin (2003) penelitian kualitatif dimaksud sebagai jenis penelitian yang temuantemuannya tidak diperoleh melalui prosedur statistik atau bentuk hitungan lainnya. Selanjutnya, dipilihnya penelitian kualitatif karena kemantapan peneliti berdasarkan pengalaman penelitiannya dan metode kualitatif dapat memberikan rincian yang lebih kompleks tentang fenomena yang sulit diungkapkan oleh metode kuantitatif.

Proses penelitian kualitatif supaya dapat mengahasilkan temuan yang benar-benar bermanfaat memerlukan perhatian yang serius terhadap berbagai hal yang dipandang perlu. Dalam memperbincangkan proses penelitian kualitatif paling tidak tiga hal yang perlu diperhatikan, yaitu kedudukan teori, metodologi penelitian dan desain penelitian kualitatif.

\section{Disain Penelitian Kualitatif}

Berbeda dengan penelitian konvensional yang bersifat kuantitatif, dalam penelitian kualitatif, disain penelitian tidak ditentukan sebelumnya. Meskipun begitu, menurut Bogdan \&Biklen, 1982 dalam Arief Furchan, 1996) fungsi disain tetap sama yaitu digunakan dalam penelitian untuk menunjukkan rencana penelitian tentang bagaimana melangkah maju. Lincoln dan Guba (1985) mengidentifikasi unsur-unsur atau elemen-elemen disain naturalistik sebagai berikut:

\section{Penentuan fokus penelitian (initial focus for inquiry)}

Penentuan fokus penelitian dilakukan dengan memilih fokus atau pokok permasalahan yang dipilih untuk diteliti, dan bagaimana memfokuskannya: masalah mula-mula sangat umum, kemudian mendapatkan fokus yang ditujukan kepada hal-hal yang spesifik. Namun, fokus itu masih dapat berubah. Fokus sangat penting sebab tidak ada penelitian tanpa fokus, sedangkan sifat fokus tergantung dari jenis penelitian yang dilaksanakan. Misalnya, untuk penelitian fokusnya adalah masalah, untuk evaluasi fokusnya adalah evaluan, dan untuk analisis kebijakan fokusnya adalah pilihan kebijakan.

\section{Penyesuaian paradigma dengan fokus penelitian}

Pertanyaan-pertanyaan yang dapat muncul dalam penyusunan disain, diantaranya: (a) Apakah fenomena terwakili oleh konstruksi yang ganda dan kompleks (a multiciplicity of com- 
plex social contructions)?; (b) sampai di mana tingkatan interaksi antara peneliti-fenomena dan sampai di mana tingkatan ketidakpastian interaksi tersebut yang dihadapkan kepada peneliti?; (c)sampai di mana tingkatan ketergantungan konteks?; (d) apakah beralasan (reasonable) untuk menyatakan hubungan kausal yang konvensional pada unsur-unsur fenomena yang diamati ataukah hubungan antar gejala itu bersifat mutual simultaneous shipping?; (e) sampai di mana kemungkinan nilai-nilai merupakan hal yang krusial pada hasil (context and time-bound atau context and time-free generalization)?

\section{Penyesuaian paradigma penelitian dengan teori substantif yang dipilih}

Kesesuaian acuan teori yang digunakan (kalau ada) dengan sifat sosial yang diacu sangat penting dalam penelitian kualitatif. Dalam penelitian kualitatif apabila temuan-temuan dapat memunculkan teori dari bawah (grounded), maka penelitian tersebut dapat dilanjutkan. Teori yang muncul dari bawah ini hendaknya ajeg dengan paradigma metode yang menghasilkan teori tersebut.

\section{Penentuan di mana dan dari siapa data akan dikumpulkan}

Dalam penelitian kualitatif tidak ada pengertian populasi, samp[ling juga berbeda tafsirannya dengan metode lainnya. Dalam kualitatif, sampling merupakan pilihan peneliti tentang aspek apa, dari peristiwa pa, dan siapa yang dijadikan focus pada saat dan situasi tertentu.Oleh karena itu dilakukan terus menerus sepanjang penelitian. Artinya, tujuan sampling adalah untuk mencakup sebanyak mungkin informasi yang bersifat holistic kontekstual. Dengan kata lain, sampling tidak harus representatif terhadap populasi (penelitian kuantitatif), melainkan representative terhadap informasi holistik. Dalam merencanakan sampling dipertimbangkan langkah-langkah berikut; (a)menyiapkan identifikasi unsure-unsur awal; (b)menyiapkan munculnya sample secara teratur dan purposif; (c)menyiapkan penghalusan atau pemfokusan sample secara terus-menerus; dan (d) menyiapkan penghentian sampling. Sebagai catatan bahwa rencana-rencana tersebut hanya bersifat sementara, sebab tidak ada satupun langkah yang dapat dikembangkan secara sempurna sebelum dimulainya penelitian di lapangan.

\section{Penentuan fase-fase penelitian secara berurutan}

Dalam penelitian ditentukan tahap-tahap penelitian, dan bagaimana beranjaknya dari tahap satu ke tahap yang lain dalam proses yang berbentuk siklus. Tahapan-tahapan tersebut memiliki tiga fase pokok: Pertama. Tahap orientasi dengan mendapatkan informasi tentang apa yang penting untuk ditemukan, atau orientasi dan peninjauan. Kedua, tahap eksplorasi dengan menemukan sesuatu secara eksplorasi terfokus, dan ketiga, tahap member check dengan mengecek temuan menurut prosedur yang tepat dan memperoleh laporan akhir.

\section{Penentuan instrumentasi}

Instrumen penelitian tidak bersifat eksternal, melainkan bersifat internal yaitu peneliti sendiri sebagai instrument (human instrument). Bentuk-bentuk lain instrument boleh dipergunakan jika ada. Untuk semua penelitian naturalistic, evaluasi atau analisis kebijakan sangat bermanfaat apabila instrument manusia diorganisasi dalam satu tim, dengan keuntungan-keuntungan dalam hal peran, perspektif nilai, disiplin, strategi, metodologi, cek internal dan saling mendukung. 


\section{Perencanaan pengumpulan data}

Instrumen manusia yang beroperasi dalam situasi yang tidak ditentukan, di mana peneliti memasuki lapangan yang terbuka, sehingga tidak mengetahui apa yang tidak diketahui. Untuk itu maka peneliti haruslah mengandalkan teknik-teknik kualitatif, seperti wawancara, observasi, pengukuran, dokumen, rekaman, dan indikasi non-verbal. Dalam rekaman data terbagi pada dua dimensi, yaitu fidelitas dan struktur. Fidelitas mengacu pada kemampuan peneliti untuk menunjukkan bukti secara nyata dari lapangan(fidelitas tinggi, misalnya rekaman video atau audio, sedangkan fidelitas kurang, misalnya catatan lapangan). Sedangkan dimensi struktur meliputi terstrukturnya wawancara dan observasi.

\section{Perencanaan prosedur analisis}

Analisis data dilakukan sepanjang penelitian dan dilakukan secara terus-menerus dari awal sampai akhir penelitian. Pengamatan tidak mungkin tanpa analisis untuk mengembangkan hipotesis dan teori berdasarkan data yang diperoleh. Analisis data merupakan proses pelacakan dan pengaturan secara sistematis transkip-transkip wawancara, catatan lapangan, dan bahan-bahan lain agar peneliti dapat menyajikan temuannya. Analisis data melibatkan pengerjaan pengorganisasian, pemecahan dan sintesis data serta pencarian pola-pola, pengungkapan halhal yang penting dan penentuanapa yang dilaporkan. Karena banyaknya model analisis yang diajukan oleh para pakar, maka peneliti hendaknya memilih salah satu modfel yang dianjurkan oleh para pakar tersebut.

\section{Perencanaan logistik}

Perencanaan perlengkapan (logistik) dalam penelitian kualitatif dapat dikelompokkan ke dalam lima kategori, yaitu: (a)mempertimbangkan kebutuhan logistic awal secara keseluruhan sebelum pelaksanaan proyek; (b)logistik untuk kunjungan lapangan sebelum, berada di lapangan; (c) logistik untuk sewaktu di lapangan; (d) logistik untuk kegiatan-kegiatan setelah kunjungan lapangan; dan (e) perencanaan logistik untuk mengakhiri dan menutup kegiatan.

Pemeriksaan keabsahan data dalam penelitian kualitatif meliputi empat teknik. Pertama, kredibilitas (credibility)yaitu criteria untuk memenuhi nilai kebenaran dari data dan informasi yang dikumpulkan. Artinya, hasil penelitian harus dapat dipercaya oleh semua pembaca secara kritis dan dari responden sebagai informan. Untuk hasil penelitian yang kredibel, terdapat tujuh teknik yang diajukan yaitu: perpanjangan kehadiran peneliti/pengamat (prolonged engagement), pengamatan terus-menerus (persistent observation), triangulasi (triangulation), diskusi teman sejawat (peer debriefing), analisis kasus negative (negative case analysis), pengecekan atas kecukupan referensial (referencial adequacy checks), dan pengecekan anggota(member checking).

Kedua, transferabilitas (transferability). Kriteria ini digunakan untuk memenuhi criteria bahwa hasil penelitian yang dilakukan dalam konteks (setting) tertentu dapat ditransfer ke subyek lain yang memiliki tipologi yang sama.

Ketiga, dependabilitas (dependability). Kriteria ini dapat digunakan untuk menilai apakah proses penelitian kualitatif bermutu atau tidak, dengan mengecek: apakah si peneliti sudah cukup hati-hati, apakah membuat kesalahan dalam mengkonseptualisasikan rencana penelitiannya, 
pengumpulan data, dan pengintepretasiannya. Teknik terbaik yang digunakan adalah dependability audit dengan meminta dependent dan independent auditor untuk mereview aktifitas peneliti.

Keempat, konfirmabilita (confirmability). Merupakan kriteria untuk menilai mutu tidaknya hasil penelitian. Jika dependabilitas digunakan untuk menilai kualitas dari proses yang ditempuh oleh peneliti, maka konfirmabilitas untuk menilai kualitas hasil penelitian, dengan tekanan pertanyaan apakah data dan informasi serta interpretasi dan lainnya didukung oleh materi yang ada dalam audit trail.

\section{HASIL DAN PEMBAHASAN}

\section{Evolusi kebijakan perdagangan Indonesia}

Era globalisasi layaknya dua sisi mata uang dimana disatu sisi memberikan peluang yang sangat besar bagi setiap Negara untuk mendorong pembangunan ekonomi dengan peningkatan ekspor, namun disisi lain juga memberikan ancaman yang cukup besar yang dapat menghambat pembangunan ekonomi itu sendiri. Dalam merespon dampak tersebut, maka peran pemerintah menjadi sangat strategis dalam konteks mengamankan lalu lintas perdagangan agar dapat berkontribusi bagi pembangunan ekonomi domestik. Pembukaan pasar domestik yang luas tentu tidak hanya difahami sebagai lahan peningkatan ekspor yang lebih tinggi, namun juga harus diyakini sebagai pendorong perbaikan kualitas daya saing industri-industri yang ada.

Secara umum, Indonesia memiliki sebuah kebijakan yang relatif sama dengan kebijakankebijakan perdagangan yang ada di Asia Tenggara dimana kebijakan perdagangan diarahkan pada dua titik Sfokus, yaitu: kebijakan substitusi impor dan kebijakan promosi ekspor. Namun sedikitnya ada lima fase pembangunan industry dan kebijakan perdagangan internasional Indonesia. Pertama, Fase pertumbuhan ekonomi yang tinggi di tahun 1967-1973. Di era tersebut telah terjadi sebuah pergantian kepemimpinan dari Soekarno ke Soeharto yang mana permasalahan-permasalahan ekonomi dilimpahkan pada kepemimpinan yang baru, yaitu: Tingginya Inflasi (630\%), tingkat pengangguran yang tinggi, pertumbuhan ekonomi yang rendah $(0.5 \%)$ dan defisit anggaran pemerintah yang tinggi. Dalam fase ini, dua kebijakan penting yang dikeluarkan pemerintahan Soeharto adalah pembukaan aliran modal masuk yang besar serta regulasi yang mengatur dan melindungi investasi asing masuk untuk melakukan aktivitas investasi.

Selanjutnya, fase kedua di tahun 1973-1982 yang disebut sebagai fase "inward-looking". Dalam fase ini perekonomian domestic sangat diuntungkan dengan tingginya harga minyak dunia (1973-4 dan 1979-81) dan komoditas lainnya (1975-1979). Keadaan ini tentu saja membawa dampak tingginya pendapatan Negara serta meningkatkan nilai tukar perdagangan (TOT-term of trade) Indonesia. Namun beberapa pakar ekonomi menyebutkan Indonesia sebagai " a missed opportunity economy", atau sebagai sebuah Negara yang tidak mampu mengambil kesempatan emas meski kekayaan alam sangatlah banyak. Era ini dijelaskan sebagai era yang sangat buruk dalam konteks "good governance" pemerintah dengan kebijakan-kebijakan yang sangat protektif dalam perdagangan dan infant industry, serta maraknya Korupsi, Kolusi dan Nepotisme (KKN). 
Dalam fase ini dijelaskan bahwa kebijakan perdagangan Indonesia lebih pada kebijakan yang bercenter pada pemerintah untuk pengembangan industry (state-directed industrialization) serta kebijakan substitusi impor yang tinggi namun tidak efisien. (Hill, 1997 dan Karseno, 1997)

Dalam fase kedua ini terdapat bipolar pandangan yang diwakilkan oleh pandangan Teknokrat dan Economic Nationalist. Pandangan pertama, yaitu "Economic Nationalist" mengedepankan self-sufficiency dalam pangan. Dalam konteks ini mereka menekankan pada kebijakan swasembada pangan, promosi penggunaan teknologi tinggi tepat guna, kebijakan padat modal untuk industry-industri besar. Kebijakan-kebijakan tersebut harus dimiliki oleh pemerintah, disubsidi dan diproteksi dari impor. Kebijakan-kebijakan inilah yang mendominasi kebijakan pemerintah yang pada saat itu sedang diuntungkan oleh keuntungan minyak guna mendorong pembiayaan investasi public dan perusahaan milik pemerintah (state-owned enterprise). Kemudian pandangan lain, teknokrat, menekankan pada kebijakan yang berorientasi pasar (market forces).

Ketiga, fase 1982-1985 merupakan masa sulit perekonomian domestik yang diakibatkan oleh penurunan harga minyak dunia yang menyebabkan terkoreksinya pertumbuhan ekonomi domestik serta negatifnya neraca pembayaran (Balance of Payment) Indonesia di tengah tahun 1980an. Dalam konteks ini, pemerintah harus mengalami fiscal shocks karena diharuskan melakukan pembiayaan subsidi terhadap perusahaan-perusahaan milik Negara. Dalam fase ini, pandangan kaum teknokrat mendominasi kebijakan-kebijakan makroekonomi Indonesia, seperti: sound macroeconomic policies, reformasi perbankan serta devaluasi terhadap mata uang Indonesia. Kebijakan reformasi pajak dimulai sejak tahun 1984, dan reformasi kebijakan perdagangan dimulai tahun 1985.

Keempat, tingginya eksternal shocks yang terjadi tahun 1986-1988 karena turunnya harga minyak dunia dan komoditas-komoditas lainnya serta hutang luar negri yang meningkat karena apresiasi Yen mendorong kebijakan pemerintah untuk tidak bergantung pada perdagangan komoditas sumber daya alam, namun beralih pada sektor manufaktur. Awal inilah yang juga mendorong kebijakan pemerintah untuk mendorong pertumbuhan ekonomi dengan kebijakan promosi ekspor. Dalam kebijakan ini, perusahaan swasta menjadi tulang punggung pendorong pertumbuhan ekonomi dan ekspor. Namun pertumbuhan ekonomi yang tinggi ini mengalami hambatan yang cukup besar tatkala masalah "cronyism" menghantui kebijakan-kebijakan ekonomi domestik dengan melakukan proteksi yang sangat besar terhadap perusahaan domestik seperti mobil nasional "Timor".

Terakhir, fase kelima dimana krisis ekonomi dan moneter terjadi di Indonesia di tahun 1997. Depresiasi rupiah dan instabilitas ekonomi, sosial dan politik telah mempengaruhi perekonomian domestic yang mengalami depresi yang berat. Dalam konteks ini, tekanan lembagalembaga donor internasional dalam kebijakan makroekonomi Indonesia dan kebijakan perdagangan telah menghasilkan beberapa kebijakan, antara lain: pengurangan non-tariff impor untuk komoditas pertanian serta pengurangan tarrif impor untuk industri automobile. Selanjutnya produk komoditas kimia, besi dan baja secara gradual dikurangi proteksinya dengan penurunan tariff impor mencapai $5-10 \%$, selanjutnya komoditas lain seperti gandum diberi pembebasan tarrif impor. (Widodo, 2008) 


\section{Pola perdagangan dan daya saing Indonesia}

Di tahun 2001, pasar ekspor kunci bagi Indonesia antara lain: Asia Tenggara (26\%), Jepang (15\%) dan NAFTA-North America Free Trade Area (16\%) yang didominasi oleh Amerika Serikat. Dalam perkembangannya, pasar ekspor Asia Tenggara mencatat pertumbuhan yang cukup signifikan, meningkat dari pangsa $15 \%$ di tahun 1990 menjadi 26\% di tahun 2001. Kontribusi ini disebabkan karena meningkatnya ekspor Negara-negara intra-ASEAN yang meningkat hingga $16 \%$ dari ekspor komoditas non-oil.

Namun, pola perdagangan Indonesia yang didominasi dengan tujuan Negara berkembang sangat berbeda dengan apa yang dilakukan oleh China. Di Negara China, Negara-negara maju menjadi tujuan ekspor utama komoditas-komoditas domestik. Dalam konteks ini, sebenarnya Negara-negara berkembang memiliki hambatan tariff yang cukup tinggi jika dibandingkan dengan Negara-negara maju. Meski patut diakui juga bahwa kebijakan non-tarrif di Negara-negara maju menjadi sebuah hambatan tersendiri yang harus dipecahkan bagi Negara-negara berkembang ketika menjamah pangsa ekspor Negara maju.

Pertumbuhan ekspor Indonesia mengalami penurunan yang cukup signifikan sejak kejadian WTC (World Trade Center) yang menyebabkan pelemahan permintaan global yang mengancam resesi dunia. Namun sejalan dengan perjalanan waktu, pertumbuhan ekspor Indonesia mengalami pertumbuhan yang cukup baik di beberapa sector, seperti: Tekstil, Sepatu, kayu dan Kulit. Hal ini disebabkan karena di tahun 2003, terjadi wabah SARS di beberapa Negara-negara eksportir di Asia Tenggara sehingga menyebabkan pergeseran permintaan dari Negara-negara Asia Tenggara ke Indonesia. ${ }^{5}$

Meski pertumbuhan ekspor Indonesia mengalami perbaikan, namun patut difahami juga bahwa Indonesia masih mengalami permasalahan supply yang sifatnya sistemik. Beberapa hal yang mempengaruhi permasalahan pertumbuhan ekspor domestik, antara lain: Ekonomi biaya tinggi (high cost economy), Kebijakan industry yang buruk, meningkatnya upah minimum regional dan kondisi infrastruktur yang buruk.

Dapat dijelaskan berdasarkan Data Statistik, bahwa di tahun 1985-1995 pertumbuhan ekspor Indonesia didominasi oleh peningkatan pangsa pasar (market share), namun di tahun 19952001, pertumbuhan ekspor didominasi oleh permintaan yang meningkat. Berdasarkan hasil observasi yang dilakukan oleh Basri dan Soesastro (2005), sebagian besar komoditas ekspor Indonesia mengalami penurunan yang cukup signifikan dalam pangsa pasar, kecuali: minyak sawit, printing and writing paper dan elektronik.

5 Pertumbuhan ekspor sepatu, tekstil dan kulit meningkat hingga 7.5\%, sedangkan ekspor kayu meningkat hingga $6.9 \%$. pada bulan Januari-juli 2003, pertumbuhan ekspor tekstil meningkat lebih dari $5 \%$. (Basri dan So esastro, 2005) 
Tabel 1. Decomposition of Indonesia's export changes

\begin{tabular}{|l|r|r|r|r|r|r|}
\hline \multirow{2}{*}{ Partner } & \multicolumn{2}{|c|}{ Export Changes, 1995-2001 (\$mill) } & \multicolumn{2}{c|}{ Export Changes, 1995-2001 (\$mill) } \\
\cline { 2 - 7 } & $\begin{array}{c}\text { Demand } \\
\text { Factor }\end{array}$ & $\begin{array}{c}\text { Competitive } \\
\text { Factor }\end{array}$ & Diversification & $\begin{array}{c}\text { Demand } \\
\text { Factor }\end{array}$ & $\begin{array}{c}\text { Competitive } \\
\text { Factor }\end{array}$ & Diversification \\
\hline China & 43059 & 131306 & 271 & 53155 & 318560 & 200 \\
\hline $\begin{array}{l}\text { Hongkong, } \\
\text { China }\end{array}$ & 12601 & -14747 & -244 & 72668 & -39096 & -4700 \\
\hline Indonesia & 7164 & 5460 & 461 & 19129 & 20828 & 333 \\
\hline Korea & 21546 & 14179 & 1 & 74832 & 49337 & 363 \\
\hline Malaysia & 18280 & 3601 & 342 & 43462 & 43146 & 796 \\
\hline Philippines & 4649 & 17574 & 24 & 22844 & 12843 & -71 \\
\hline Singapore & 27809 & -29677 & -734 & 48574 & 15041 & 770 \\
\hline $\begin{array}{l}\text { Taiwan, } \\
\text { China }\end{array}$ & 27963 & -4814 & 117 & 112240 & 1096 & -251 \\
\hline Thailand & 8907 & 5811 & 414 & 14857 & 44655 & 232 \\
\hline Vietnam & 520 & 7640 & -18 & 403 & 13310 & -74 \\
\hline & & & & & & \\
\hline $\begin{array}{l}\text { All Above } \\
\text { Countries }\end{array}$ & 172498 & 136333 & 634 & 462164 & 479720 & -2402 \\
\hline & 11675 & -97126 & -5259 & 516344 & -152427 & -9313 \\
\hline Japan & 103104 & -132464 & -791 & 506926 & -232044 & -15647 \\
\hline $\begin{array}{l}\text { European } \\
\text { Union (15) }\end{array}$ & 160661 & -33740 & -37 & 754854 & -112113 & -12225 \\
\hline NAFTA & & & & & & \\
\hline
\end{tabular}

Sumber: UN COMTRADE Statistics

Berdasarkan tabel 2 di bawah ini dapat dijelaskan bahwa tren komoditas manufaktur berdasarkan perhitungan RCA (Revealed comparative Advantage) di tahun 1985-1995 mengalami peningkatan. Namun, sejak tahun 1995-2001, hampir seluruh produk (kecuali, plywood, tekstil, sepatu dan garmen) mengalami penurunan yang cukup signifikan. Hal ini menjelaskan bahwa di tahun 1985-1995, pertumbuhan ekspor didominasi oleh daya saing (competitiveness) yang meningkat. Namun keadaan ini berubah sejak tahun 1995, dimana partumbuhan ekspor disebabkan karena permasalahan dari sisi demand. Hal ini juga merefleksikan bahwa pertumbuhan ekspor disebabkan karena masalah sisi supply. 
Tabel 2. Indonesia's Manufacturing Products' Revealed Comparative Advantage 1985-2001

\begin{tabular}{|c|c|c|c|c|}
\hline $\begin{array}{c}\text { SITC- } \\
4\end{array}$ & Product (Revision 2) & 1985 & 1995 & 2001 \\
\hline 6342 & $\begin{array}{l}\text { Plywood consisting of sheets of } \\
\text { woo }\end{array}$ & & $\rightarrow 4$ & \\
\hline 6349 & Wood, simply shaped,n.e.s. & & 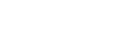 & \\
\hline 6597 & Plaits and similar products of plaits & & 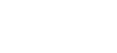 & \\
\hline 6343 & Improved wood and reconstituted & & - & \\
\hline 6353 & Builders' carpentry and joinery & & 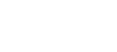 & \\
\hline 8421 & Overcoats and other coats, men,s & & $\rightarrow$ & 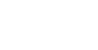 \\
\hline 7511 & Typewritters; cheque-writting machin & & $\rightarrow$ & 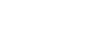 \\
\hline 6516 & Yarn of discont.synth.fibres, contai & & 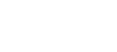 & 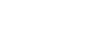 \\
\hline 8432 & Suits \& costumes,women's, of textile & & $\rightarrow$ & - \\
\hline 8510 & Footwear & & 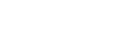 & \\
\hline 6354 & $\begin{array}{l}\text { Manufactures of wood for } \\
\text { domestic/d }\end{array}$ & & 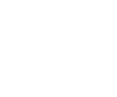 & \\
\hline 8443 & Under garments, women, $s_{;}$of textile $f$ & & & \\
\hline 6423 & $\begin{array}{l}\text { Registers, exercise books, note } \\
\text { books }\end{array}$ & & - & \\
\hline 6531 & Fabrics, woven of continuous synth.t & & 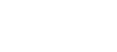 & \\
\hline 8442 & Under garments, excl.shirts, of texti & & 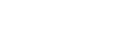 & \\
\hline 8433 & Dresses, women"s, of textile fabrics & & $\rightarrow$ & 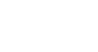 \\
\hline 7628 & $\begin{array}{l}\text { Other radio-broadcast receivers } \\
\text { Cotton }\end{array}$ & & $\rightarrow$ & $>$ \\
\hline 6521 & fabrics, woven, unbleached, not & & & \\
\hline 5621 & Mineral or chemical fertilizers, nit & & $\mathbf{-}$ & \\
\hline 6581 & Sacks and bags, of textile materials & & $\rightarrow$ & $\rightarrow$ \\
\hline
\end{tabular}

Sumber: Calculated from UN COMTRADE statistics

Penurunan performa ekonomi Indonesia selain disebabkan oleh permasalahan sisi penawaran (supply side problems) juga disebabkan karena tingginya proteksi yang dilakukan pemerintah Indonesia terhadap industry-industri domestik. Permasalahan yang krusial disini bukan karena proteksi semata, namun diperparah karena yang mendrive proteksi adalah tingginya KKN (Korupsi Kolusi dan Nepotisme). Sehingga kebijakan proteksi yang dilakukan tidak tepat sasaran dan hanya menciptakan inefisiensi yang semakin lebar. Kebijakan ini tentu bertentangan dengan kesepakatan multilateral perdagangan global dibawah naungan WTO-World Trade Organization. Dalam kesepakatan yang diratifikasi oleh member WTO, kebijakan proteksi 
tentu dilarang karena akan menyebabkan "Tradewar" atau perang kebijakan proteksi yang dapat menimbulkan kebekuan dalam perdagangan multilateral.

Pemerintah Indonesia telah melakukan kebijakan proteksi baik dalam bentuk kebijakan tariff maupun non-tarrif. Namun perkembangan kebijakan tariff mengalami penurunan yang cukup signifikan yang dilakukan oleh Departemen Keuangan, disisi lain kebijakan non-tarif yang dilakukan oleh kementrian perdagangan dan perindustrian menunjukan peningkatan proteksi. Meski begitu, Basri dan Hill (2004) menjelaskan bahwa kebijakan proteksi Indonesia masih lebih rendah jika dibandingkan dengan Negara-negara Asia lainnya, termasuk Thailand.

Selanjutnya reformasi kebijakan perdagangan Indonesia setelah krisis diwarnai oleh paketpaket kebijakan perdagangan atas mandat dari IMF (International Monetary Fund) yang disebut sebagai "conditions". Hal ini berbeda dengan Negara-negara lain, seperti Thailand dan Paket kebijakan IMF yang menyertakan kebijakan perdagangan didalamnya.

Di Indonesia, program penyesuaian structural memasukan penurunan kebijakan tariff di beberapa sector seperti: Bahan Kimia, Besi dan Baja dan Produk perikanan hingga 5-10\%. Selanjutnya beberapa komoditas seperti: Wheat and Wheat flour, kacang kedelai dan bawang harus diimpor secara bebas bagi importer-import berlisensi.

Untuk komoditas Wheat and Wheat flour, pemerintah menurunkan kebijakan tariff dari $10 \%$ menjadi $5 \%$ di tahun 2003. Namun pemerintah menekan penurunan hingga $0 \%$ namun kembali ke 5\% di tahun 2002. Dalam program reformasi struktural lainnya, sector pertanian mengalami deregulasi perdagangan yang sangat tinggi. Dalam sektor ini, clove marketing board dihilangkan. Di sektor investasi, hambatan investasi baik yang sifatnya formal dan informal dihilangkan di sektor "palm oil" dan semen. Keadaan-keadaan tersebut menjelaskan bahwa kebijakan perdagangan Indonesia relative terbuka dengan dikuranginya secara signifikan kebijakan-kebijakan tariff dan non-tariff.

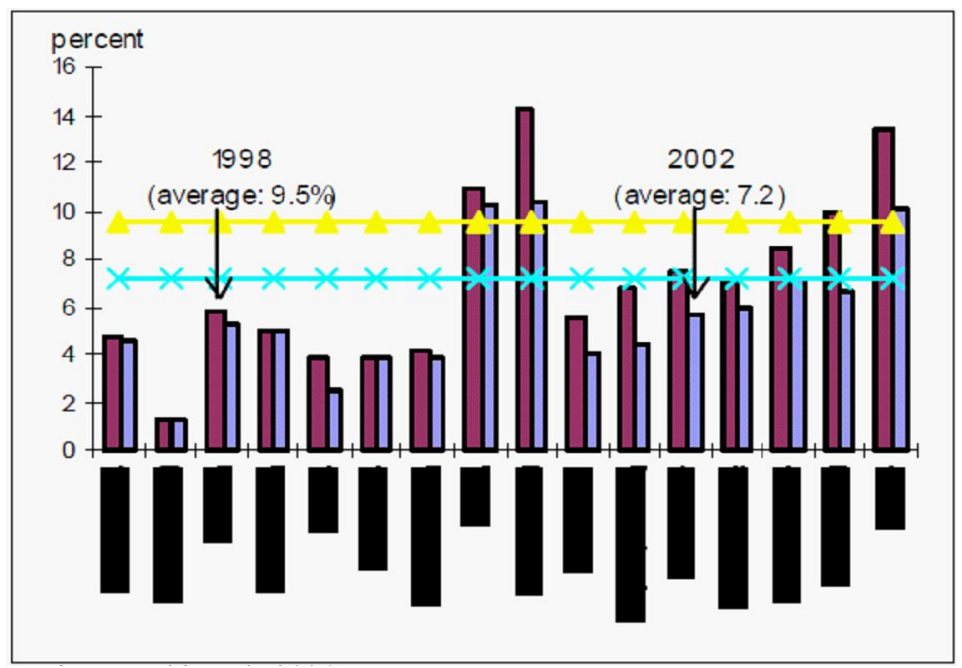

Gambar 1. Tariff averages by 2-digit ISIC, 1998 and 2002

Sumber: World Bank (2004) 


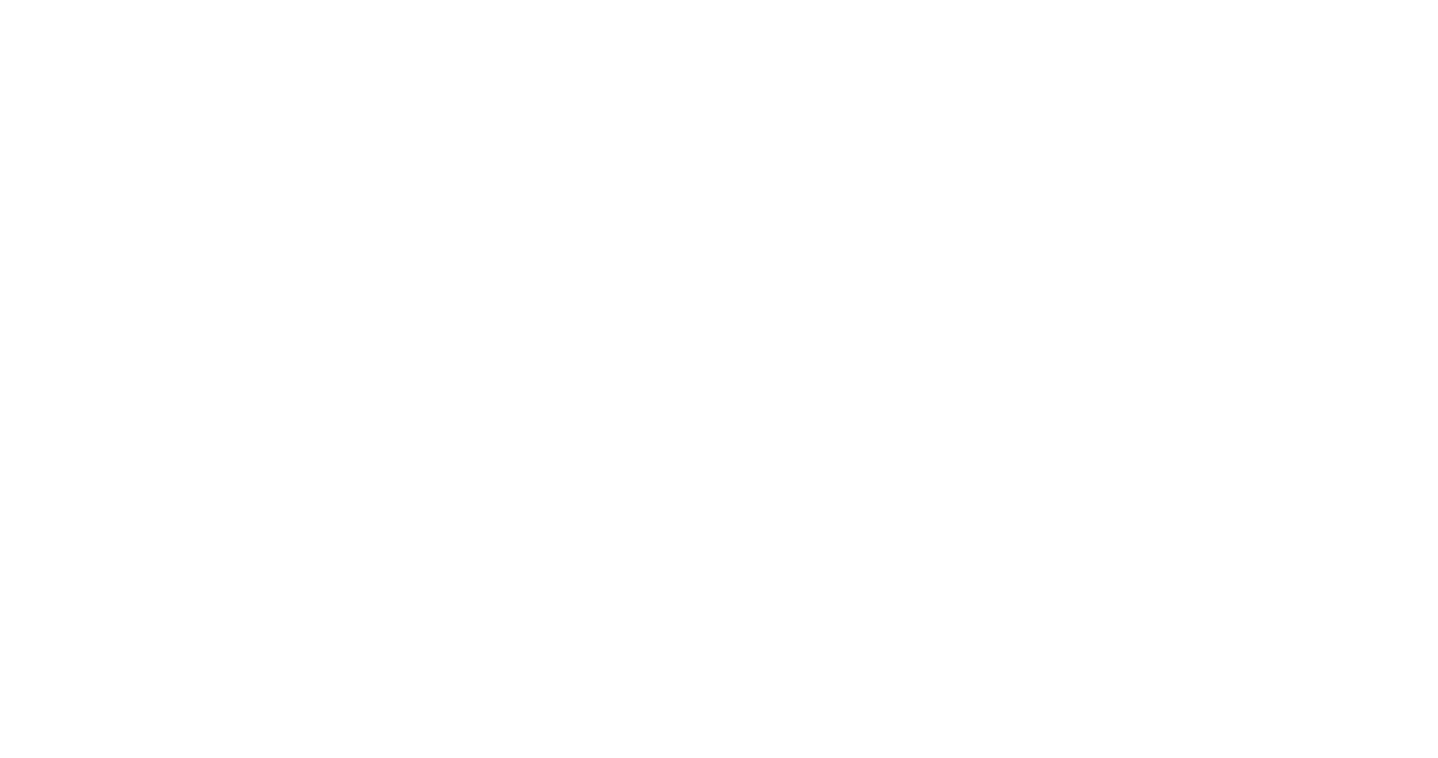

Gambar 2.

Tabel 4 di bawah ini menjelaskan bahwa kebijakan proteksi pemerintah di sector manufaktur lebih tinggi dibandingkan dengan sector pertanian di tahun 2000, didasarkan pada perhitungan ERP (Effective Rate of Protection) dan NRP (Nominal Rate of Protection). Secara umum nilai NRP sector manufaktur mencapai $11.4 \%$, nilai ini lebih tinggi dibandingkan NRP sector pertanian yang hanya mencapai 5.0\%. Selanjutnya perhitungan ERP disektor manufaktir menunjukan tingkat proteksi yang sangat tinggi mencapai $25.7 \%$, jauh diatas ERP sector pertanian yang hanya mencapai 5.8\%. Meski nilai ini menunjukan tingkat proteksi yang sangat tinggi di sector manufaktur, namun bukan berarti pemilik modal mendapatkan keuntungan dari proteksi tersebut. Hal ini disebabkan karena kebijakan non-tarif telah diconvert menjadi kebijakan tariff sejak tahun 1995. Hal ini berbeda dengan sector pertanian yang masih melakukan kebijakan non-tarif untuk mendukung sektor pertanian, seperti: kebijakan subsidi, kuota impor dan kebijakan lain seperti dalam komoditas gula dan beras.

Tebel 4 Average effective rate of protection (ERP) and nominal rate of protection (NRP) in the Indonesian Agriculture and Manufacturing Sectors, 2000

\begin{tabular}{|l|c|c|c|c|}
\hline \multirow{2}{*}{ IO 2000 } & \multicolumn{2}{|c|}{ ERP } & \multicolumn{2}{c|}{ NRP } \\
\cline { 2 - 5 } & Average $^{*}$ & $\begin{array}{l}\text { Standard } \\
\text { Deviation }\end{array}$ & Average* $^{\text {Standard Deviation }}$ \\
\hline $\begin{array}{l}\text { Agriculture } \\
\text { (Sector 1-34) }\end{array}$ & 5.8 & 5.2 & 5.0 & 4.5 \\
\hline $\begin{array}{l}\text { Manufacture } \\
\text { (Sector 49-141) }\end{array}$ & 25.7 & 51.2 & 11.4 & 20.6 \\
\hline Total & 20.6 & 57.3 & 10.5 & 41.4 \\
\hline
\end{tabular}

Note: * Weight average based on sectors

Sumber: 
Dapat dijelaskan bahwa crony-capitalist sangat mendominasi kebijakan perdagangan yang ada di Indonesia dan telah menjadi hambatan terbesar dalam liberalisasi perdagangan di Indonesia. Meski patut diakui juga, pembukaan pasar yang terlalu besar juga dapat diidentifikasi sebagai salah satu penyebab krisis di Indonesia. Meski era kepemimpinan Soeharto telah mengalami pergeseran kearah system yang lebih demokratis namun hal ini tidak menjamin aktivitas perilaku mencari rente (rent seeking behavior) dan patrimonialism. Dalam konteks ini, masih ada sebuah intervensi ekstra diluar pemerintahan yang mempengaruhi kebijakan-kebijakan dibeberapa sektor, seperti pertanian. Di sector tersebut, kebijakan yang sifatnya politis masih membungkusi kebijakan-kebijakan ekonomi domestik guna menyelamatkan kepentingan-kepentingan jangka pendek.

Secara sektoral pertanian dapat dijelaskan bahwa perkembangan nilai ekspor produk pertanian Indonesia di ASEAN dengan metode CMS (Constant Market Share) yang dilakukan oleh Hadi dan Mardianto (2004) mengalami penurunan pangsa dan nilai ekspor. Hal ini secara umum disebabkan karena rendahnya rekayasa dan inovasi teknologi yang semakin menurunkan keunggulan biaya dan keunggulan kualitas. Apabila dicermati 24 kelompok produk pertanian Indonesia dapat dijelaskan bahwa dari 24 kelompok, 10 kelompok mengalami penurunan yang negatif. Beberapa komoditas yang bernilai positif merupakan komoditas-komoditas unggulan Indonesia, seperti: CPO; sayur dan umbi-umbian; kopi, the dan rempah, serta Kakao. Selanjutnya hasil observasi lapang yang dilakukan dapat dijelaskan bahwa ekspor sayuran dari Sumatera Utara ke Singapura dan Malaysia mengalami penurunan karena kompetisi serupa dari Vietnam, China dan Pakistan untuk komoditas kubis, Ubi Jalar dan Kentang.

\section{Evaluasi Penyelenggaraan Kebijakan Perdagangan dalam kerangka Sistem Ekonomi Nasional}

Arah penyelenggaraan ekonomi termasuk kebijakan perdagangan di Indonesia jelas tertuang dalam Pasal 33 Ayat 1 UUD 1945 yang berbunyi: "Perekonomian disusun sebagai usaha bersama berdasar atas asas kekeluargaan”. Selain itu, salah satu kewajiban negara dalam bidang ekonomi yaitu seperti yang diamanatkan oleh Pasal 34 yang berbunyi: "Fakir miskin dan anak-anak yang terlantar dipelihara oleh Negara". Namun realitas yang masih jauh dari amanat konstitusi memerlukan suatu rumusan sistem ekonomi nasional yang secara filosofis sesuai dengan falsafah dan secara teknis dapat diimplementasikan.

Selanjutnya amanat yang tertuang dalam Pancasila dan UUD 1945 merupakan fondasi bagi kehidupan bernegara untuk seluruh bidang, baik itu ekonomi, sosial, budaya, hukum, dan lain-lain. Hal ini jugalah yang mengarahkan setiap kebijakan agar tidak keluar dari nilai-nilai dasar Pancasila dan UUD 1945. Secara umum sistem ekonomi nasional mengarah pada pembangunan ekonomi untuk mencapai kesejahteraan masyarakat secara merata. Dalam konteks ini, maka kebijakan pemerintah harus diarahkan pada pembuatan regulasi yang tepat bagi pencapaian visi dan misi amanah Pancasila dan UUD 1945. 
Berdasarkan nilai-nilai setiap sila dalam Pancasila, dapat disimpulkan bahwa asas sistem ekonomi nasional adalah kekeluargaan, kebersamaan, dan gotong royong. Selanjutnya untuk menjamin tercapainya kesejahteraan yang berkualitas maka proses penyelenggaraan kehidupan ekonomi yang adil saja belum cukup karena masih harus dilengkapi dengan prinsip kemanfaatan.

Tujuan pembangunan yang hanya menempatkan pertumbuhan ekonomi semata merupakan sebuah kekeliruan. Sehingga tujuan pembangunan ekonomi bukan cuma mengejar pertumbuhan ekonomi, namun juga pertumbuhan yang seiring dengan pemerataan (growth with equality). Oleh karena itu, perdebatan antara pertumbuhan dan ketimpangan seharusnya dapat diminimalisir, di mana salah satunya dengan jalan melakukan pembangunan berdasarkan sektor basis yang menyerap sebagian besar tenaga kerja.

Sistem ekonomi nasional yang digunakan di Indonesia berlandaskan pada nilai dan substansinya mengacu pada UUD 1945. Sebab, UUD 1945 merupakan landasan pokok dalam penyelenggaraan negara, termasuk penyelenggaraan kehidupan ekonomi. Setidaknya ada empat elemen penting dalam sistem ekonomi nasional, yaitu (1) tujuan yang ingin dicapai yaitu kesejahteraan masyarakat, (2) model kepemilikan sumber daya, (3) mekanisme penyelenggaraan kegiatan ekonomi, dan (4) pelaku ekonomi dan regulasi.

Kesejahteraan merupakan komponen terpenting sebagai tujuan sistem ekonomi nasional karena keberadaannya bersifat mutlak. Sistem ekonomi bisa berbeda antara satu negara dengan negara lainnya, tetapi semua sistem ekonomi menuju pada satu tujuan yang sama, yaitu kesejahteraan.

Kepemilikan merupakan faktor mendasar dalam pendistribusian pendapatan dan kesejahteraan. Sebab, perolehan pendapatan dari setiap pelaku ekonomi sangat ditentukan oleh besarnya sumber daya yang disumbangkan dalam kegiatan ekonomi. Kalau seluruh faktor produksi yang digunakan dalam proses produksi hanya dimiliki oleh satu orang, maka seluruh pendapatan yang dihasilkan menjadi milik yang bersangkutan saja. Sebaliknya, jika faktor produksi dimiliki oleh orang banyak dan dengan pembagian kepemilikan yang merata, maka semakin merata pula pembagian pendapatan. Oleh karena itu, pemerataan dalam kepemilikan sumber daya merupakan syarat utama untuk menciptakan pemerataan pendapatan dan kesejahteraan.

Secara garis besar, sumber daya dapat dibagi dalam dua kelompok, yaitu sumber daya alam dan sumber daya hasil karya manusia. Sesuai dengan UUD 1946, sumber daya alam dikuasai oleh negara (bumi, air, dan kekayaan alam yang terkandung di dalamnya). Alasan dikuasai oleh negara karena undang-undang memposisikan negara sebagai penguasa tertinggi bangsa Indonesia, sehingga tidak selayaknya negara dipandang sebagai pemilik, tetapi sebagai penguasa.

Sesuai dengan kedudukannya sebagai penguasa tertinggi, maka tugas negara adalah melindungi dan mensejahterakan rakyatnya. Oleh karena itu, Pasal 33 Ayat 3 UUD 1945 menyebutkan SDA dikuasai negara dan digunakan sebesar-besarnya bagi kemakmuran rakyat. Jadi, tujuan dikuasai oleh negara bukan untuk tujuan kekuasaan itu sendiri, tetapi kekuasaan yang digunakan untuk mewujudkan kesejahteraan. Oleh karena itu, makna dikuasai oleh negara diperluas pengertiannya menjadi wewenang negara untuk mengatur, mengurus, mengelola dan mengawasi. 
1. Mekanisme sosial politik yang berlaku saat ini dan yang diharapkan di masa datang.

2. Sikap atau mentalitas masyarakat terhadap kegiatan ekonomi.

3. Tingkat pendidikan rata-rata masyarakat, khususnya pengetahuan tentang kegiatan ekonomi.

4. Kecanggihan lembaga ekonomi yang dimiliki, seperti pasar, sistem transportasi dan komunikasi, perangkat hukum ekonomi, serta sistem perbankan.

Dalam organisasi ekonomi modern, setiap kegiatan ekonomi sesungguhnya dituntun oleh dua mekanisme, yakni pasar dan negara. Hanya saja, problem yang selalu muncul bagaimana komposisi antara negara dan pasar tersebut, serta dalam aktivitas mana negara atau pasar mesti lebih banyak berperan. Berdasarkan UUD 45 pasal 33, mekanisme pengaturan perekonomian yang berdasarkan nilai kekeluargaan dan kebersamaan bukanlah merupakan titik tengah atau kompromi antara sistem koordinasi melalui perencanaan sentralistik (hierarchy) dengan sistem koordinasi melalui pasar. Sistem koordinasi perekonomian yang berasas kekeluargaan dan kebersamaan tidak dapat diartikan sebagai suatu mekanisme pengaturan yang mengabaikan prinsip rasionalitas ekonomi, seperti prinsip-prinsip efisiensi dan keuntungan. Hanya saja, sistem ini juga mementingkan terwujudnya keadilan (equality). Artinya, mekanisme pasar haruslah menjamin terjadinya transaksi yang adil, yaitu transaksi tanpa kecurangan, ketidakjujuran, diskriminasi dan kerusakan baik dibidang ekonomi, lingkungan, dan tata-nilai masyarakat.

Prasyarat yang dibutuhkan guna menjamin agar sistem koordinasi perekonomian yang berasas kekeluargaan dan kebersamaan dapat diimplementasikan adalah adanya sistem politik demokrasi kerakyatan berdasarkan musyawarah yang berketuhanan dan kemanusian.

Berdasarkan perspektif UUD 1945, terutama dikaitkan pada penjelasan Pasal 33, peran serta masyarakat dalam aktivitas ekonomi di Indonesia direpresentasikan dalam tiga pelaku ekonomi, yakni Badan Usaha Milik Negara atau Daerah, usaha swasta, dan koperasi. Ketiga pelaku ekonomi tersebut melakukan interaksi dan interrelasi sehingga membentuk satu kesatuan perekonomian nasional. Perilaku ketiga pelaku tersebut akan sangat mempengaruhi pertumbuhan ekonomi dan juga sekaligus pola distribusi hasil pembangunan. Jika salah satu dari pelaku ekonomi melakukan kegiatan ekonomi dengan tidak efisien, maka ketidakefisienan tersebut akan menyebar pada aktivitas dari pelaku ekonomi yang lainnya.

Jika mereview kembali kebijakan-kebijakan perdagangan yang diimplementasikan di Indonesia, dapat diidentifikasi bahwa ada beberapa kebijakan perdagangan yang meleset dari nilainilai dasar UUD 1945 dan Pancasila, sehingga menyebabkan mismanagement dalam kebijakan pembangunan sehingga berpengaruh pada menurunnya tingkat kesejahteraan masyarakat secara umum. Beberapa kebijakan yang dimaksud, antara lain:

1. Kebijakan proteksi perdagangan tidak didasarkan pada prinsip penciptaan kesejahteraan dan pemerataan, namun didasarkan pada perilaku crony-capitalism.

2. Kebijakan pemerintah terkait dengan kepemilikan asing dalam berinvestasi masih belum mengindahkan nilai-nilai kemanfaatan yang luas serta prinsip kesejahteraan, keadilan dan pemerataan.

3. Kebijakan proteksi pemerintah di sektor pertanian masih belum optimal menciptakan sebuah daya saing yang tinggi, bahkan sektor ini terus mengalami penurunan seiring semakin rendahnya komitmen pemerintah dalam melindungi sektor pertanian. 
Namun patut difahami, bahwa belum optimalnya implementasi kebijakan perdagangan tentu disebabkan oleh hambatan-hambatan yang sifatnya eksternal maupun internal sehingga mempengaruhi penguatan jati diri sebagai bangsa dalam pengimplementasian nilai-nilai UUD 1945 dan Pancasila:

1. Kesepakatan konvensi internasional terkait dengan perdagangan internasional dibawah naungan WTO (World Trade Organization) mendorong implementasi kebijakan-kebijakan yang disepakati oleh Negara-negara anggota, sehingga sangat memungkinkan kebijakan tersebut tidak sesuai dengan kebutuhan sebagai bangsa. Dalam konteks ini kebijakan yang dimaksud adalah pengurangan tariff di beberapa sector yang dapat mengancam beberapa infant industry yang ada di domestik. Selanjutnya kesepakatan untuk tidak melakukan proteksi dibeberapa sector juga menyebabkan terancamnya kesejahteraan para pelaku ekonomi. Sebagai contoh pengurangan proteksi sector pertanian yang padat karya di Indonesia telah mengakibatkan kurang tumbuhnya sector ini diakibatkan masih tradisionalnya peralatan yang dimiliki oleh para petani.

2. Kesepakatan regional perdagangan internasional AFTA (ASEAN Free Trade Area) dalam bidang investasi dan perdagangan tentu saha mendorong Indonesia untuk mengurangi intervensinya terlalu jauh dalam manajeman ekonomi. Hal ini tentunya sangat mempengaruhi pencapaian target-target pembangunan yang ingin dicapai.

3. Tekanan lembaga-lembaga donor (IMF, World Bank, ADB dan lain-lain) tidak dapat dipungkiri telah mempengaruhi kebijakan ekonomi yang ada di Indonesia, seperti pengalaman yang terjadi saat krisis. Nasehat kebijakan atau yang popular dikenal sebagai "conditions" sudah merupakan sebuah kewajiban yang harus dilaksanakan ketika sebuah Negara meminta bantuan kepada lembaga-lembaga donor tersebut. Sebagai contoh, ketika krisis ekonomi, Paket kebijakan IMF mengharuskan Indonesia untuk melakukan berbagai macam kebijakan, antara lain: Privatisasi, Pengurangan tariff impor di beberapa sector, Kebijakan uang ketat serta beberapa program kebijakan structural lainnya.

4. Intervensi Negara-negara maju atau trading partner.

Kebijakan Perdagangan kedepan tentunya harus dipersiapkan secara matang guna mempersiapkan Indonesia bertanding didalam dunia global. Dalam menghadapi pentas ekonomi yang penuh kompetisi maka peran pemerintah diharapkan dapat lebih matang untuk mendorong penciptaan daya saing yang lebih baik, karena kedepan kebijakan-kebijakan dan hambatan perdagangan sudah harus ditinggalkan oleh semua Negara, termasuk Indonesia. Sebagai konsekuensi masuknya Indonesia dalam perdagangan bebas.

Seiring dengan tingginya eskalasi perdagangan bebas tentunya mendorong setiap bangsa, termasuk Indonesia untuk mengurangi intervensinya dalam memproteksi sektor-sektor tertentu. Namun tentu saja perlu kejelian pemerintah untuk tetap concern memperhatikan sektor-sektor yang strategis, seperti sektor pertanian yang mempengaruhi kesejahteraan hajat hidup orang banyak. Disisi lain, prioritas kebijakan yang bisa dilakukan oleh Indonesia adalah dengan mendorong Investasi yang lebih besar guna mendorong daya saing ekonomi yang lebih tinggi. Meski dalam kebijakan ini, pemerintah harus mulai berhati-hati untuk mengijinkan pemain asing masuk dalam aktivitas ekonomi domestik. Namun dalam konteks ini, berhati-hati bukan berarti 
menutup dari peran asing, namun mempertimbangkan secara matang cost and benefitnya bagi Indonesia.

Perekonomian Indonesia saat ini masih belum dapat bersaing secara maksimal dalam era perdagangan bebas, di sisi lain pertumbuhan Investasi domestik juga masih belum maksimal dalam mendorong pertumbuhan ekonomi dan peningkatan kesejahteraan masyarakat. Perlunya penguatan investasi dan daya saing perdagangan internasional yang tinggi ditujukan untuk semakin memperkuat eksistensi perekonomian domestik bersaing di pasar global. Karena jika tidak, maka negara kita hanya menjadi pusat eksploitasi keuntungan dari masuknya produk-produk asing ke pasar domestik.

Dalam mendorong pembangunan ekonomi yang lebih kuat dalam jangka panjang, pemerintah perlu mempersiapkan kelembagaan dan kondisi investasi yang kondusif bagi masuknya Penanaman Modal Langsung atau FDI (Foreign Direct Investment).

Pentingnya Investasi bagi pertumbuhan ekonomi secara umum telah diinventarisir dan diteliti oleh berbagai peneliti dunia, seperti Harrod-Domar (1948) yang menjelaskan bahwa investasi sangat penting terhadap pertumbuhan ekonomi karena Investasi akan meningkatkan stok barang modal yang memungkinkan dapat mendorong output. Selanjutnya Borensztein, et. al (1998), melakukan studi empiris dalam mengestimasi dampak FDI (Foreign Direct Investment) terhadap pertumbuhan ekonomi 69 negara berkembang selama periode 1970-1989. Hasil penelitian menunjukan bahwa FDI berpengaruh positif terhadap pertumbuhan ekonomi. Ketiga, Kojima (1978) melihat FDI dari sisi makroekonomi. Menurut Kojima, FDI bersifat komplemen dan mendukung pembangunan ekonomi dan negara penerima FDI. Investasi asing langsung dapat ditujukan untuk mempromosikan diversifikasi, memperbaiki struktur industri, dan mewujudkan kesejahteraan mutual antara negara investor dan negara penerima. Oleh karena itu Investasi sebagai kebutuhan bahan bakar dasar untuk percepatan pertumbuhan ekonomi harus segera dapat direalisasikan.

Ada beberapa alasan mendasar mengapa Indonesia perlu untuk berusaha menarik FDI (Foreign Direct Investment) di wilayah ini, antara lain:

1. FDI diharapkan dapat menutup kekurangan modal domestik.

2. FDI diharapkan adanya technology transfer dan transfer of knowledge dari perusahaan asing ke domestik.

3. Adanya FDI diharapkan dapat meningkatkan kesempatan kerja dan mengurangi masalah pengangguran.

4. FDI diharapkan dapat meningkatkan devisa negara melalui peningkatan dalam ekspor.

Namun demikian banyak kritik dan kontra terhadap FDI, antara lain:

1. Dampak kegiatan perusahaan asing cenderung tidak merata dan mempertajam kesenjangan pendapatan.

2. Dalam jangka panjang FDI dapat mengurangi penerimaan devisa baik pada neraca berjalan maupun pada neraca lalu lintas modal. Memburuknya neraca berjalan dikarenakan impor barang modal dan barang setengah jadi yang dilakukan oleh perusahaan asing. Sedangkan memburuknya neraca lalu lintas modal dikarenakan adanya transfer keuntungan, pembayaran bunga dan royalti, pembayaran lisensi, serta management fee. 
3. Alih teknologi dan manajemen dalam kenyataannya seringkali tidak terjadi

4. Perusahaan-perusahaan asing seringkali dapat mematikan perusahaan-perusahaan domestik

5. Perusahaan asing sering menarik keuntungan yang besar dan mereka sendiri sedikit menanamkan kembali keuntungan yang diperolehnya

6. Perusahaan-perusahaan asing seringkali menghasilkan barang-barang yang tidak dibutuhkan oleh rakyat banyak

7. Keringanan pajak dan kemudahan lain yang sering ditawarkan kepada perusahaanperusahaan asing sering berlebihan. Padahal fasilitas yang sama tidak diberikan kepada perusahaan domestik

8. perusahaan asing seringkali mempertajam kesenjangan pembangunan desa dan kota karena perusahaan asing umumnya berlokasi di perkotaan. Hal ini menimbulkan efek terhadap arus urbanisasi.

Oleh karena itu untuk dapat mendapatkan manfaat yang besar dari masuknya investasi langsung dari Penanaman Modal Asing (PMA) dan Penanaman Modal Dalam Negeri (PMDN), pemerintah sebagai regulator harus dapat sebisa mungkin memberikan fasilitasi dan dukungan pada proses-proses transfer knowledge dan transfer technology. Selain itu, pemerintah juga diharapkan secara konsisten untuk dapat mempayungi sisi kelembagaan dan pengaturan investasi yang masuk ke Indonesia agar dapat mendukung efisiensi performa bisnis mereka.

Seperti yang dijelaskan pada bagan dibawah ini, bahwa transfer of knowledge dari adanya Penanaman Modal Asing atau FDI terhadap kemampuan menyerap teknologi di domestik sangat memerlukan dukungan pemerintah dalam proses tersebut. Selain itu, tugas pemerintah juga menjadi penting dalam konteks menciptakan kondisi investasi yang kondusif, pengembangan infrastruktur serta penguatan kompetensi yang kuat. Hal ini dilakukkan sebagai bagian pengembangan human capital dan produktivitas ekonomi dalam penerapan teknologi tinggi dan tepat guna.

Selanjutnya dibutuhkan framework kebijakan yang menyeluruh dan fasilitasi bisnis guna mendukung aktivitas ekonomi FDI di Indonesia. Tabel dibawah ini merupakan ringkasan strategi yang secara umum dapat direalisasikan untuk dapat mendukung FDI di Indonesia.

Dalam konteks menghadapi era perdagangan global yang ramai dengan persaingan, Indonesia harus mampu melihat permasalahan globalisasi dengan lebih jeli karena perdagangan internasional sendiri tanpa support pemerintah yang kuat, tidak akan mampu memberikan solusi dalam pengentasan kemiskinan. Sehingga perlu ada upaya untuk menyelaraskan strategi pengentasan kemiskinan dan liberalisasi perdagangan internasional. Hal ini tentunya sangat terkait dengan peran pemerintah untuk memberikan dukungan yang jelas dan sehat dalam penindakan korupsi, pengaturan kompetisi dalam dunia usaha, penjagaan market access serta pembangunan infrastruktur. Untuk dapat mengambil kesempatan dalam perdagangan internasional, ada beberapa strategi yang penting untuk dapat mensupport perekonomian domestik agar dapat bersaing di pasar internasional.

Pertama, negara miskin dan berkembang membutuhkan fasilitas transportasi dan telekomunikasi yang mapan. Kedua, negara miskin dan berkembang membutuhkan modern custom facility. Ketiga, negara miskin dan berkembang membutuhkan suatu infrastruktur 
laboratorium yang dapat digunakan dalam proses pengujian produk-produk ekspor, sehingga standar dan kualitas produk dalam negri dapat terjaga dengan sempurna. Keempat, negara miskin dan berkembang membutuhkan jaringan pengamanan keuangan yang berfungsi dalam mengantisipasi shock yang datang baik dari dalam (internal) maupun dari luar (eksternal). Kelima, negara miskin dan berkembang membutuhkan tenaga ahli yang concern dalam masalah perdagangan internasional. Tenaga ahli ini juga menyangkut ahli yang berkaitan dengan upaya negosiasi, penyelesaian hukum internasional (dispute and settlement) dan ahli dibidang ekonomi internasional. (Stiglitz, 2006) Pembangunan ekonomi yang telah dipaparkan sebelumnya tentu akan menjadi lebih bermakna jika memiliki pengaruh yang luas dalam penciptaan lapangan kerja, pengurangan kemiskinan dan distribusi pendapatan. Hal ini menjadi sangat penting untuk mendukung stabilitas sosial masyarakat yang berkembang searah dengan pembangunan ekonomi.

\section{E. KESIMPULAN DAN REKOMENDASI}

\section{Kesimpulan}

1. Meski pertumbuhan ekspor Indonesia mengalami perbaikan, namun patut difahami juga bahwa Indonesia masih mengalami permasalahan supply yang sifatnya sistemik. Beberapa hal yang mempengaruhi permasalahan pertumbuhan ekspor domestik, antara lain: Ekonomi biaya tinggi (high cost economy), kebijakan industri yang buruk, meningkatnya upah minimum regional dan kondisi infrastruktur yang buruk.

2. Jika mereview kembali kebijakan-kebijakan perdagangan yang diimplementasikan di Indonesia, dapat diidentifikasi bahwa ada beberapa kebijakan perdagangan yang meleset dari nilai-nilai dasar UUD 1945 dan Pancasila, sehingga menyebabkan mismanagement dalam kebijakan pembangunan sehingga berpengaruh pada menurunnya tingkat kesejahteraan masyarakat secara umum. Beberapa kebijakan yang dimaksud, antara lain: Pertama) Kebijakan proteksi perdagangan tidak didasarkan pada prinsip penciptaan kesejahteraan dan pemerataan, namun didasarkan pada perilaku crony-capitalism. Kedua) Kebijakan pemerintah terkait dengan kepemilikan asing dalam berinvestasi masih belum mengindahkan nilai-nilai kemanfaatan yang luas serta prinsip kesejahteraan, keadilan dan pemerataan. Ketiga) Kebijakan proteksi pemerintah di sektor pertanian masih belum optimal menciptakan sebuah daya saing yang tinggi, bahkan sektor ini terus mengalami penurunan seiring semakin rendahnya komitmen pemerintah dalam melindungi sektor pertanian.

3. Namun patut difahami, bahwa belum optimalnya implementasi kebijakan perdagangan tentu disebabkan oleh hambatan-hambatan yang sifatnya eksternal maupun internal sehingga mempengaruhi penguatan jati diri sebagai bangsa dalam pengimplementasian nilai-nilai UUD 1945 dan Pancasila: Pertama) Kesepakatan konvensi internasional terkait dengan perdagangan internasional di bawah naungan WTO (World Trade Organization) mendorong implementasi kebijakan-kebijakan yang disepakati oleh Negara-negara anggota, sehingga sangat memungkinkan kebijakan tersebut tidak sesuai dengan kebutuhan sebagai bangsa. Dalam konteks ini kebijakan yang dimaksud adalah pengurangan tariff di beberapa sector yang dapat mengancam beberapa infant industry yang ada di domestik. Selanjutnya kesepakatan untuk tidak melakukan proteksi dibeberapa sector juga menyebabkan teran- 
camnya kesejahteraan para pelaku ekonomi. Sebagai contoh pengurangan proteksi sector pertanian yang padat karya di Indonesia telah mengakibatkan kurang tumbuhnya sector ini diakibatkan masih tradisionalnya peralatan yang dimiliki oleh para petani. Kedua) Kesepakatan regional perdagangan internasional AFTA (ASEAN Free Trade Area) dalam bidang investasi dan perdagangan tentu saha mendorong Indonesia untuk mengurangi intervensinya terlalu jauh dalam manajeman ekonomi. Hal ini tentunya sangat mempengaruhi pencapaian target-target pembangunan yang ingin dicapai. Ketiga) Tekanan lembagalembaga donor (IMF, World Bank, ADB dan lain-lain) tidak dapat dipungkiri telah mempengaruhi kebijakan ekonomi yang ada di Indonesia, seperti pengalaman yang terjadi saat krisis. Nasehat kebijakan atau yang popular dikenal sebagai "conditions" sudah merupakan sebuah kewajiban yang harus dilaksanakan ketika sebuah Negara meminta bantuan kepada lembaga-lembaga donor tersebut. Sebagai contoh, ketika krisis ekonomi, Paket kebijakan IMF mengharuskan Indonesia untuk melakukan berbagai macam kebijakan, antara lain: Privatisasi, Pengurangan tariff impor di beberapa sector, Kebijakan uang ketat serta beberapa program kebijakan structural lainnya. Keempat) Intervensi Negara-negara maju atau trading partner.

4. Kebijakan Perdagangan kedepan tentunya harus dipersiapkan secara matang guna mempersiapkan Indonesia bertanding didalam dunia global. Dalam menghadapi pentas ekonomi yang penuh kompetisi maka peran pemerintah diharapkan dapat lebih matang untuk mendorong penciptaan daya saing yang lebih baik, karena kedepan kebijakan-kebijakan dan hambatan perdagangan sudah harus ditinggalkan oleh semua Negara, termasuk Indonesia. Sebagai konsekuensi masuknya Indonesia dalam perdagangan bebas.

5. Seiring dengan tingginya eskalasi perdagangan bebas tentunya mendorong setiap bangsa, termasuk Indonesia untuk mengurangi intervensinya dalam memproteksi sektor-sektor tertentu. Namun tentu saja perlu kejelian pemerintah untuk tetap concern memperhatikan sektor-sektor yang strategis, seperti sektor pertanian yang mempengaruhi kesejahteraan hajat hidup orang banyak. Disisi lain, prioritas kebijakan yang bisa dilakukan oleh Indonesia adalah dengan mendorong Investasi yang lebih besar guna mendorong daya saing ekonomi yang lebih tinggi. Meski dalam kebijakan ini, pemerintah harus mulai berhati-hati untuk mengijinkan pemain asing masuk dalam aktivitas ekonomi domestik. Namun dalam konteks ini, berhati-hati bukan berarti menutup dari peran asing, namun mempertimbangkan secara matang cost and benefitnya bagi Indonesia.

\section{Rekomendasi}

1. Dengan adanya kajian atas konstitusi ekonomi dan kebijakan perdagangan internasional diharapkan dapat mendorong pemerintah untuk lebih concern dalam memformulasikan kebijakan yang tepat bagi kesejahteraan masyarakat Indonesia.

2. Pemerintah diharapkan terus melakukan penguatan kelembagaan perdagangan internasional mengingat tingginya tekanan kompetisi yang mempengaruhi perekonomian domestik.

3. Penelitian lebih lanjut diharapkan dapat mengisi kekosongan gap penelitian dibidang konstitusi ekonomi khususnya tentang kebijakan perdagangan, penelitian kedepan diharapkan dapat melakukan telaah yang lebih kritis dimasing-masing sector ekonomi. 


\section{DAFTAR PUSTAKA}

Agus Salim 2006.Teori \& Paradigma Penelitian Sosial. Yogyakarta: Tiara Wacana

Anderson, J. E. 2008. The New Palgrave Dictionary of Economics . Boston, Massachussetts, United States: Boston College.

Anderson, K. 2001. Globalization, WTO, and ASEAN. ASEAN Economic Bulletin, Vol. 18, No. 1 : 12-23.

Asshiddiqie, Jimly. 2010. Konstitusi Ekonomi, Penerbit Buku Kompas.

Australian Industry Group. 2005. An ASEAN - Australia \& New Zealand Free Trade Agreement. Sydney: Australian Industry Group.

Bank of Tokyo-Mitsubishi UFJ. 2009. Free Trade Agreement in Asia: A Progress Report. Tokyo: Bank of Tokyo-Mitsubishi UFJ.

Brannen, Julia. 1997. Memadu Metode Penelitian Kualitatif \& Kuantitatif. Terj, Nuktaf Arfawie Kurde, Imam Safe'I dan Noorhaidi. Yogyakarta: Pustaka Pelajar.

Capra, Fritjof. 2001. Tao of Physics.Menyingkap Paralisme Fisika Modern dan Mistisisme Timur. Terjemahan Pipit Maizer. Yogyakarta: Jalasutra.

Capra, Fritjof. 2000 Titik Balik Peradaban Sains, masyarakat dan Kebangkitan Kebudayaan. Terjemahan M. Thoyibi. Yogyakarta: Yayasan Benteng Budaya.

Christie, E. 2002. Potential Trade in Southeast Europe: A Gravity Model Approach. Balkan Observatory Journal .

Chua, S. C. 2000. ASEAN: Economic Integration and Intra-Regional Trade. Applied Economics Letters. 165-169.

Field, D. R. 1998. International Economics: Trade Theory and Policy. Singapore: The McGraw Hill.

Groot, G.-J. M. 2006. Estimation of the Gravity Equation in the Presence of Zero Flow. Amsterdam: Tibergen Institute.

Ikemoto, R. J. 2004. AFTA and the Asian Crisis: Help or Hindrance to ASEAN Intra-Ragional Trade. Asian Economic Journal, Vol. 18, (No. 1).

Kehoe, R. B. 2003. Trade Theory and Trade Facts. Minneapolis: Federal Reserve Bank of Minneapolis.

Lexy J. Moleong. 1989. Metodologi Penelitian Kualitatif. Bandung: Remadja Karya

Lili Rasjidi. 1991. Manajemen Riset Antardisiplin, editor. Bandung: Rosda

Lincoln, Yvonna S \& Egon G. Guba. 1985. Naturalistic Inquiry. California: Sage

Maurice J.G. Bun, F. J. 2009. Free Trade Areas and Intra-Regional Trade: The Case of ASEAN.

Mauro, F. D. 2000. The Impact of Economic Integration on FDI and Exports: A Gravity Approach. Centre for European Policy Studies . 
Mubyarto, Loekman Sutrisno dan Michael Dove. 1984. Nelayan dan Kemiskinan. Studi Ekonomi dan Antropologi di Dua Desa Pantai. Jakarta: Rajawali.

Myrdal, Gunnar. 1969. The political Element in the Development of Economic Theory. New York: Simon and Schuster.

Nuryadin, A. A. 2007. Perdagangan Bilateral Indonesia-Jepang dan Dampaknya terhadap Volatilitas Nilai Tukar Riil. Jurnal Ekonomi Indonesia, (No. 2) : 81-95.

Paiva, C. 2005. Assessing Protectionism and Subsidies in Agriculture: A Gravity Approach. Washington DC: International Monetary Fund Institute.

Panjaitan, B. 2008. Analisis Hubungan Perdagangan ASEAN dan Australia. Jakarta: Fakultas Ekonomi Universitas Indonesia.

Rietveld, H. L.-J. 2003. Why do OECD-countries trade more?. Amsterdam: Tinbergen Institute.

Roberts, B. A. 2004. A Gravity Study of the Proposed China-ASEAN Free Trade Area. The International Trade Journal, Vol. 18 (No. 4) : 335-353.

Sala-i-Martin, X. 2009. Global Competitiveness Report 2009-2010. Switzerland: World Economic Forum.

Salvatore, D. 1993. International Economics. New York: Macmillan.

Smith, Adam. 1976. An Inquiry into tThe Wealth of Nations. Chicago: The University of Chicago.

Sokchea, K. 2007. An Analysis of Cambodia's Trade Flows: A Gravity Model. Social Science Research Network Journal .

Symon, Gillian \& Catherine Cassell.1998. Qualitative Methods and Analysis in Organizational Research. A Practical Guide. New Delhi: Sage

Weber, Max.1960. Sekte-sekte Protestan dan Semangat Kapitalisme dalam Taufik Abdullah, editor. 1979. Agama, Etos Kerja dan Perkembangan Ekonomi. Jakarta: LP3ES. 